\title{
19. Religion, Politics and the Election in the Southern Highlands
}

\author{
Richard Eves
}

This chapter looks at the issue of religion and politics in the 2007 election in the Southern Highlands, focusing specifically on the Kagua-Erave Open electorate (Figure 19.1).

The great diversity in forms of religion in Papua New Guinea means that it is unwise to attempt to generalize about the effects of religion on politics. Although almost everybody in the country today identifies as Christian, the churches are very large in number and are widely divergent in beliefs and policies. ${ }^{1}$ Further, each denomination has its own local character, influenced in part by the many popular local religions drawn from traditional beliefs which remain extremely potent. In some areas, Christianity and local religion have been drawn on to produce elaborate syncretic forms of religion which are highly influential and some of which take great interest in the political arena.

In this analysis I focus on Christianity, since it is this element of religion that appears to be having the widest and most visible effect on politics in Papua New Guinea. The mainstream churches-Lutheran, Catholic, United and Anglican - have a long history and remain by far the largest Christian grouping. However, the most spectacular growth in the last decade or so has been in converts to the 'born again' evangelical, charismatic and Pentecostal churches, which have such appeal that they are making rapid inroads on the traditionally large congregations of the mainstream churches. I focus mainly on these more recent forms of religious expression, partly because they are increasingly dominating the religious landscape but also for the more practical reason that it was these groups that I encountered in the area where I was working during the 2007 election.

1 According to Operation World, 97.28 percent of the population is Christian today (2008). 


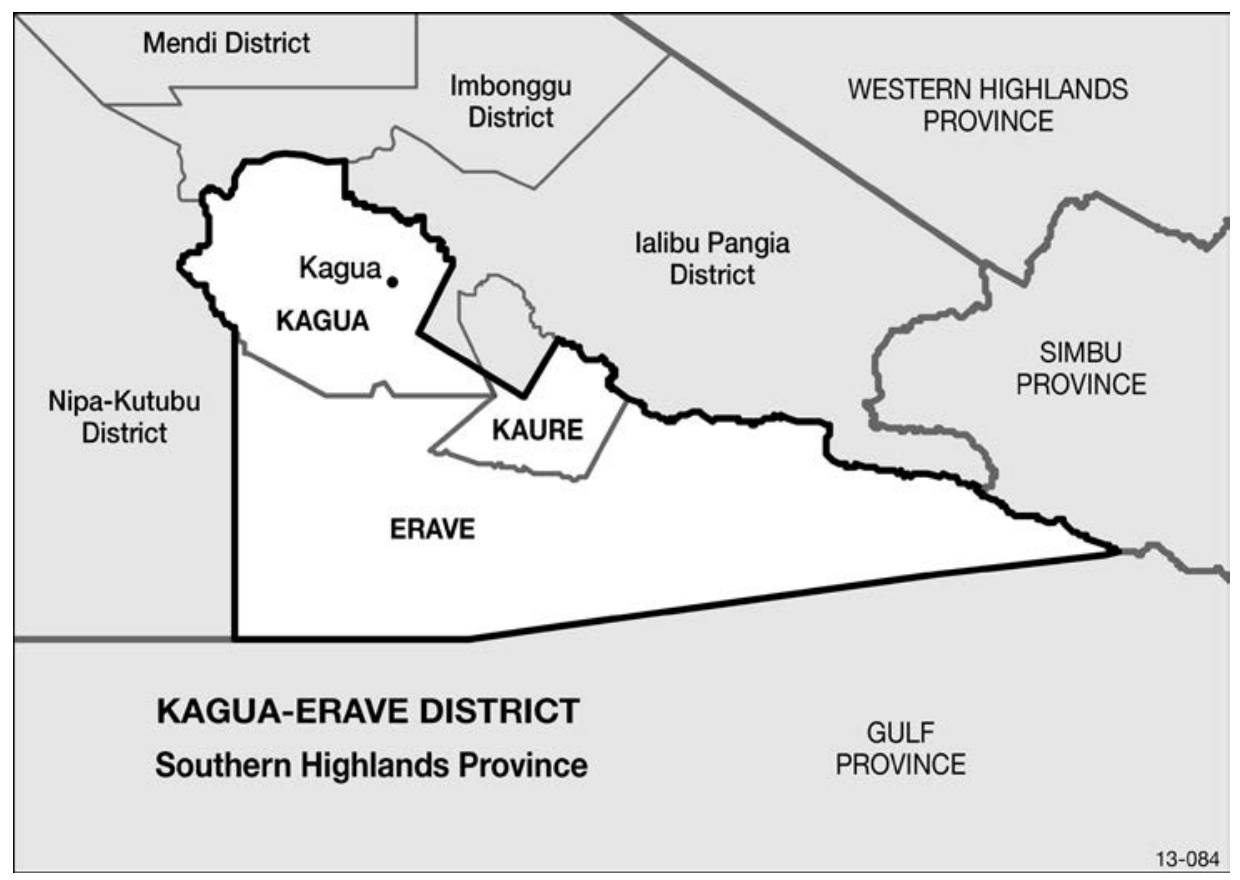

\section{Figure 19.1: Kagua-Erave District}

Most of the new evangelical, charismatic and Pentecostal churches are fundamentalist, since they read the Bible literally and take an extremely dualist view of the world, as a dire struggle between good and evil. They shun active involvement in politics, avoiding engagement with the state in both civil society and electoral affairs (see Hauck, Mandie-Filer and Bolger 2005:22; Gibbs 2005:17). ${ }^{2}$ This general aloofness towards politics has been described as 'political acquiescence' (Schoffeleers 1991:89) ${ }^{3}$ and indeed some of these churches do endorse the belief that people should accept the authority of the government of the day (Gibbs 2004:4, 2005:18; Hauck, Mandie-Filer and Bolger 2005:22). ${ }^{4}$ This does not mean that they do not have what Ireland refers to as, 'critical citizenship' - a critique of the social and political economies of the country in which they live (1995:136). Indeed these churches often articulate trenchant criticism of the corruption and the inability of the Papua New Guinea state to deliver services. Much of this criticism is cloaked in a particular kind of conspiratorial and apocalyptic language, as evident in the discussions with local pastors I describe below. These critiques rarely generate political activism;

\footnotetext{
2 Much diversity characterizes the approach of conservative Protestants around the world to involvement in politics. A considerable literature explores the issue.

3 How 'political acquiescence' is defined can present something of a problem, according to Schoffeleers, since what seems like acquiescence to one party may be described by another as a subtle form of resistance, or as the best a church can manage in a situation (1991:90). He concludes that a church is 'acquiescent', when its policy is to avoid political activism of a critical nature.

4 Romans 13:1-7 is usually invoked in this context (Gibbs 2005:18 and 2004:4).
} 
rather they are reactive, expressing an emotional feeling of moral outrage towards those responsible for corruption and poor governance. These problems are seen as evidence that people are not living Christian lives, and the remedy is for people to become good Christians, the emphasis being on individual moral reform rather than broader social reform, and to pray for God's intervention for a good election result (Gifford 1991:18). Some commentators argue that such Christians are not passive spectators in political affairs since they use prayer in the hope of influencing outcomes. Sometimes this is framed in terms of 'spiritual warfare', conceived as an active challenge to Satan's power through aggressive prayer (Jorgensen 2005:446). However, while it is true that this activity reveals the existence of interest in outcomes, it is hardly effective action.

This chapter describes specific aspects of the 2007 election to show how politics and religion were interrelated. It is divided into two sections: the first deals initially with the national context and then with the Southern Highlands; the second section moves in to look more closely at the Kagua-Erave Open electorate, to examine the perspectives of a local candidate and several pastors from the village where he was based.

\section{The 2007 election}

The 2007 election bore some similarities to previous elections and also significant differences. Discussing the relationship between politics, religion and churches in the 2002 election, Philip Gibbs suggests there was a blurring between the sacred and the secular, with political discourse and symbolism laced with Biblical and other Christian imagery. This involved candidates assiduously seeking to present themselves as 'God-fearing' people who could be trusted. The Saviour was also a common figure and Gibbs cites several examples of candidates comparing themselves to Moses leading the exodus from Egypt to the Promised Land.

Also in the 2002 election, some candidates made extravagant promises to Christians to secure their vote. Peter Yama, the candidate for Usino-Bundi Open, declared that he would 'ensure that $10 \%$ of the annual national budget is given to God', proposing a tithing policy which would distribute 10 percent of Papua New Guinea's total earnings to churches through the Home Affairs Department (cited Gibbs 2004:7; see also 2005:3). ${ }^{5}$ In 2007, the People's Freedom Party made

5 This is not the first time this has been raised. Gibbs cites a case from 1987 in which the member for Alotau, Iairo Lasaro, quoting from the Old Testament prophet Malachi (3:7-12), stated in parliament, 'I believe if this nation makes the first move to allow 10 percent of its budget to God, this country according to the word, God himself will open the windows of heaven and pour out more blessings in this nation. Law and order, tribal fights, natural disasters and all other problems, I can assure this Government that God will guarantee the total security of this nation' (Hansard 20 November 1987:22-24 cited in Gibbs 2005). 
similar promises, advocating support for the churches and non-government organizations by voluntary tithing of 10 percent of the tax revenue. However, none of this party's eight candidates succeeded in winning a seat. Other political parties and candidates were more restrained in their promises on this issue, simply saying they would support the work of the churches.

Christian rhetoric was a persistent theme in the People's Freedom Party statement that appeared in the Post-Courier. They considered it very important that the question of leadership be addressed before problems of development: leaders must be 'truly repentant and resolved towards the God Almighty, oneself, family and community' (Post-Courier, Election Special, June 2007). Leaders must also be physically fit, possibly a reference to the widespread idea that bodily health, especially outward appearance, is an indication of moral health (see Eves 1998:28-29, 1996). In the same paper, other Christians upheld Jesus as the model of leadership, defined in terms of 'shepherd-ship, servant-ship and sacrifice' (ibid.). The Pangu Pati's policy platform included creating a ministry of religion: 'Pangu acknowledges the role of the church in promoting Christian values, and in social, economic, and spiritual development, and proposes to create a Ministry of Religion to improve government-church cooperation' (ibid.).

A significant difference between the election of 2007 and earlier ones was the absence of a nationwide campaign like 'Operation Brukim Skru', which had featured in the lead-up to the 1997 election (see Schmid 1999; Gibbs 2005; Jorgensen 2005). Literally meaning to bend the knee, but conveying connotations of kneeling down to pray or seeking forgiveness, Brukim Skru was initiated at Government House in November 1996 by the governor-general of the time, Sir Wiwa Korowi. Brukim Skru aimed 'to bring PNG before God for his divine intervention for the evils of our time' (Asia Pacific Network 1997). ${ }^{6}$ A large number of churches was involved in this campaign, though Gibbs suggests that the initiative came mostly from the conservative evangelical and Pentecostal churches (2005:14). One plan, which evidently had the support of the Electoral Commissioner but which did not quite get off the ground, was to provide 'prayer cover' to keep corruption and evil spirits away during polling. ${ }^{7}$

Operation Brukim Skru also involved local events, such as 'crusades', including a 'Mega Prayer Crusade' at the University of Papua New Guinea, organized by the Tertiary Student's Christian Fellowship, which involved students praying for good government. As the president of the Tertiary Student's Christian Fellowship, Bill Koim, commented at the time:

6 He was refuting claims by the National Intelligence Organisation that members of Brukim Skru were involved in the Sandline crisis which brought down the government of the day.

7 The original plan was to have 20,000 Christian volunteers in this role, but when polling began only a few hundred offered their services (Gibbs 2005:15; see also Jorgensen 2005:449). 
We have been praying for a good government and honest leadership, and we have not been surprised to see a lot of the established leaders fall. We are not saying that they were bad leaders, but we are thankful because these are God's own doings (The National 9 July 1997, cited in Schmid 1999:20).

He added that the underlying theme of the crusade was that politicians needed the strength of God to perform well in the new government, human strength and wisdom being only secondary (ibid.:21). Since the country had lost its way, only divine intervention could help it to follow the right path.

The 2007 election had no nationwide campaign like Brukim Skru but prayer was still considered a useful strategy. This occurred at the local level but it was also widely advocated in the national discourse, with correspondents to the newspapers urging people to pray for the right leaders to be elected.

\section{We want God-fearing leaders}

In 2007, as in 2002, a common campaign theme noted by Gibbs was the image of the God-fearing leader (see Figure 19.2). Indeed, the need for God-fearing candidates and elected members was echoed constantly in popular discourse. It was aired on the faith page of the National newspaper when it reported on a radio talkback show involving several church pastors who warned voters to choose God-fearing leaders and to be wary of those candidates who hardly ever attend church but who now, during the election campaign, carry Bibles and speak in Biblical terms. Such people, they warned, were not true leaders but were merely 'switching to become "holy now" in order to lure voters' (The National 5 July 2007). By contrast, the most appropriate leaders were those who maintained their integrity, honesty, loyalty and righteousness (ibid.). ${ }^{8}$

The meaning of God-fearing was often unspecified but it was not simply synonymous with Christian; one person interviewed by the Post-Courier seeing them as two quite different things (Post-Courier, Election Special, June 2007). A young student from the National Capital District, who was actually too young to vote, thought that a 'leader should be responsible, transparent and one who promotes people's interests'. Such a leader should be God-fearing meaning that he would be dependent on God's wisdom and guidance, which would prevent him from being corrupt (ibid.). Another student, eligible to vote, commented that she would not be voting for wantok and would cast her vote for a God-fearing, 'hardworking' and 'reliable' leader. Another saw Godfearing as describing a person who abides by the principles of the Bible and

8 These pastors commended the prime minister for dedicating the nation to God during a Prayer Day ceremony during the year (The National 5 July 2007). 
'therefore has the heart to serve the people' (ibid.). Others saw God-fearing in terms of 'honesty', 'transparency' and 'trustworthiness'. God-fearing conveys connotations of being fearful of God, putting the idea of a retributive God who punishes those who do not behave in a Christian manner. Others did not take up the God-fearing terminology, seeing the need simply for a Christian, particularly one with high Christian values and principles, since a person like this would 'most likely conduct himself according to Biblical principles' (ibid.).

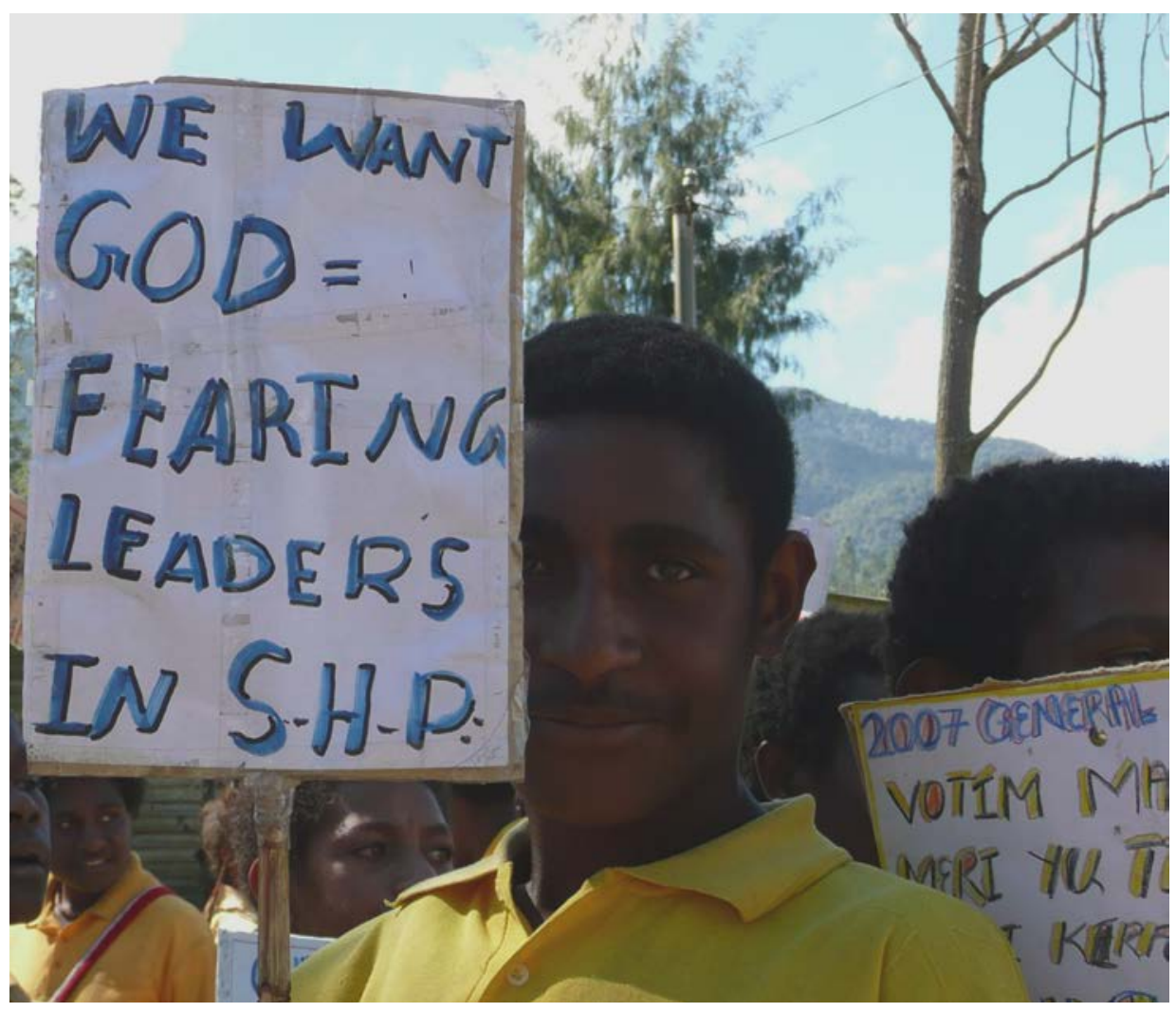

Figure 19.2: 'We want God-fearing leaders in Southern Highlands Province' 


\section{The view from the Southern Highlands}

Christianity featured less prominently in the Southern Highlands than it did nationally. With some exceptions, most Southern Highlands Province candidates avoided direct reference to their religious affiliation or beliefs. ${ }^{9}$ While some mentioned the need for God-fearing leaders and some used Christian imagery, religion did not predominate as it has in the past. Posters, in particular, focused almost entirely on secular and factual matters. Although a few election posters did give details of a broader policy agenda, they were very sketchy on the whole, presenting only basic details, such as a photograph with the name of the candidate, and asking for people's votes. For example, the election poster of Dickson Pena Tasi, a regional candidate, displayed no policies and no slogans, featuring only his name, his picture (complete with cowboy hat decorated with bird of paradise feathers) and a request for voters to write his name or number in box 1,2 or 3 .

Only one of the 20 or so posters displayed outside the largest Mendi store invoked the image of a 'God-fearing leader'. This one, promoting Paru Hagnai, standing for the Tari-Pori Open seat and endorsed by the Papua New Guinea Labour Party, announced that he stood for 'God-fearing leadership', 'justice for the people', 'transparency/accountability for the people' and 'economic prosperity for the people'.

I saw no images of Jesus on election posters or billboards in the Southern Highlands, as was reported elsewhere during the 1997 election (Gibbs 2005:7), although a few featured more subtle Christian allusions. One striking example of this was provided by Anderson Agiru, the successful candidate for the Southern Highlands Provincial seat or governorship, who used several slogans with a Christian resonance. Declaring that it was time to 'kirapim' (resurrect) the province, he announced that it was the 'Dawn of a New Future', an image which echoes the evangelic rhetoric of being born again. On another poster, he presented himself as a humble Christian, saying, 'My best is not enough, Lord Almighty!'. Since Agiru was aiming to be governor for the second time, his publicity was replete with suggestions of resurrection and veiled allusions to the second coming. One of his billboards, placed prominently in Mendi, showed him in shirt and tie, with raised fist, looking very much like a Bible-thumping preacher (see Figure 19.3).

9 Pastor David Ongol Paki, an independent for the SHP Provincial seat, for example, gave his policies as: '1. Spiritual Development 2. Free Education 3. Health Services 4. Infrastructure Development 5. Agriculture and Livestock Development 6. Justice, Fairness and Equality' (campaign poster). 


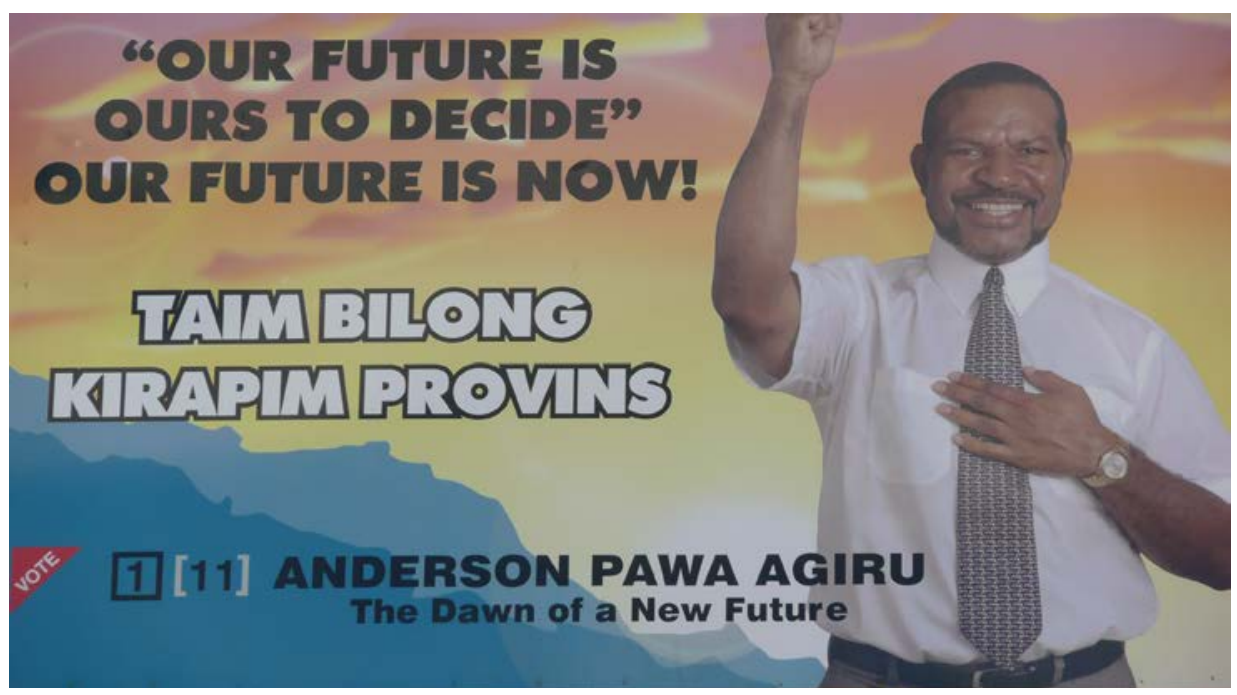

Figure 19.3: Anderson Agiru billboard, Mendi

This recourse to Christian imagery surpassed even those church leaders who stood as candidates, whose slogans were comparatively straightforward and not nearly as cleverly crafted as Agiru's. One pastor invoked a saying from Proverbs, declaring on his poster that: 'Righteousness exalts a nation' (while omitting the second clause which says 'but sin is a reproach to any people') (Proverbs 14:34). Pastor Francis Apurel, standing for the SHP Provincial seat with Agiru, simply announced that he was for 'Progress and development-God's way'. In the extensive policy platform on his poster, Thomas Handolwa, though not a pastor or preacher, wanted to reinforce church activities, and also included promoting community development, agriculture and tourism. Makire Tom (independent, standing for the provincial seat) produced the only poster to mention AIDS, although this is a major calamity confronting Papua New Guinea. He construed this as a question of Christian morality, advocating the promotion of good ways to avoid AIDS ('HIV/AIDS-Promotim ol Gutpela Pasin bilong Abrusim Sik $\left.A I D S^{\prime}\right)$, with its obvious reference to abstinence and faithfulness.

It was noticeable that those candidates who did articulate some Christian discourse rarely identified themselves with any particular denomination, except for the candidates who were pastors or priests, who usually gave their clerical title. This suggests not only that, due to the overwhelmingly dominance of Christianity in Papua New Guinea, Christian identity is being taken for granted, but also that, with the increasing fragmentation of the mainstream churches and the proliferation of smaller churches, it is expedient to direct appeals to the generic Christian. The introduction of limited preferential voting, which has brought the need to garner preferences more widely, has added to this impetus. 


\section{The election in Kagua-Erave}

In terms of organization and procedures during the election, media claims of 'successful polling' in the Southern Highlands Province were far from true for Kagua-Erave. The overwhelming consensus of those present, including voters, candidates, security personnel and even electoral officials, was that the election was a huge failure because the election was so poorly organized. People were dismayed at the inadequate electoral rolls, which omitted a great many residents' names. Also, some voters had been unable to vote because ballot papers or electoral rolls did not arrive. ${ }^{10}$ One ward, for example, received rolls and ballot papers for only four constituencies, and these were actually from another electorate. A fairly common comment was: 'Em failed eleksen, em bagarap tru'. One assistant returning officer's comment was that the electoral commission has 'failed miserably', a claim echoed by many. Another polling official commented, 'the running of the election in Kagua-Erave was very poor. The commission as a whole has failed'. Some people considered themselves in mourning, with one man from Kumbianda, who was unable to vote, commenting that: 'mipela stap long haus krai', meaning that he and others in his village were in mourning over their disenfranchisement. Some even commented that the election failure was worse than the 2002 election. This is a damning indictment, given that the 2007 election was fairly peaceful compared with 2002, when people stormed the Kagua police station, disarmed police, forced down the police helicopter and stole and destroyed ballot boxes and papers.

As one candidate remarked, the limited preferential voting system had changed people's behaviour: 'Before, the people ruined the process, but now it is the government'. Another man expressed his disappointment in the following way: 'The people are very quiet but the system is killing us'. Others, especially those whose names were omitted from the common roll, asked rhetorically which country they belong to now, since the government has rejected them: 'Gavman $i$ rejectim mipela, mipela stap long wanem kantri nau?' ('The government has rejected us, which country do we live in now?'). ${ }^{11}$

\footnotetext{
10 The ballot box for Mungaro (Aliya local-level government [LLG]) held four ballot papers (the four names on the roll were from another electorate, Imbonggu), and that for Waro (Erave LLG) held three. Pawabi (Aliya LLG), Pobu Worok 2 (Erave LLG) and Pawabi 2 (Erave LLG) all received neither ward rolls nor ballot papers. The following wards had ward rolls but no ballot papers Mendo 2 (Aliya LLG), Mapuanda (Aliya LLG), Kumbianda (Aliya LLG), Muguri (Aliya LLG) and Suiyaibu (Aliya LLG). It was not possible to vote at two polling stations in Erave LLG (Sirigi and Sopise) because the ballot papers and boxes could not be delivered before polling lapsed.

11 Unfortunately, the failure of the Electoral Commission to carry out its mandated role nourishes the profound disenchantment with the Papua New Guinea nation-state widely felt in rural communities and cities alike. Many people responded to these failings by suggesting that Australia, through institutions like AusAID, should not only run elections, but take over the governing of Papua New Guinea, since the state institutions were totally incapable of doing so. Some people even wanted the electoral commissioner to be replaced by an Australian, since they had utterly lost confidence in the ability of the current commissioner to run an election.
} 
Despite being a feature of some parties' policy statements at the national level, few candidates in Kagua-Erave overtly identified as Christian, except in the most general terms. In none of the election speeches I heard did candidates specify their church affiliation or articulate any specifically Christian themes. Probably in the interests of garnering votes from as wide a spectrum as possible, their election posters were similarly noncommittal. Neither did religion loom large in debate in the council ward where I was based during the election. Overwhelmingly, campaigning there focused on how little development there had been in the electorate and what development the candidate would bring. This is unsurprising given that the Southern Highlands is one of the least developed and most impoverished provinces in Papua New Guinea, despite having several large resource projects that generate revenue for the national and provincial governments (Haley and May 2008; Lewis 2008). Little of this revenue appears to be returned to the people of the province. The failure of development in the electorate of Kagua-Erave was largely blamed on the local member, people often commenting that they did not see any signs of his work ('mipela no lukim wanpela mak bilong memba $i$ stap long hia'). Neither had people seen any sign of him in the electorate, except during the nomination and campaign period when he was seen firing a high-powered automatic weapon during a conflict with the supporters of a rival at the district headquarters of Kagua. ${ }^{12}$ Indeed, it was a popular view that once a candidate is elected he will not be seen in the electorate for another five years, preferring to live in Port Moresby and administer the electorate by 'remote control' as it is sometimes described.

Because of inadequate government services, there is extensive pessimism about the politics and government of Papua New Guinea throughout the electorate and doubtless the whole province. The view is also widely held that many of the candidates cannot be trusted, being motivated only by self-interest. 'Politics in PNG is no good, lots of liars are involved' ('Politiks long PNG em i no gut, plenti giaman i stap insait'). It is also widely held that independence has been a failure, with many people longing nostalgically for a return to the Australian colonial government.

As in the wider province, Kagua-Erave candidates' election posters gave little information about policies, relying largely on empty slogans. For example, one candidate alluded to his past political career to claim he was: 'For Genuine, Strong and Proven Leadership', and another, standing as a Papua New Guinea Country Party candidate, proclaimed: 'We have the Answers'. One of the most elaborate posters was produced by the Pangu Pati candidate, Lalepa Patapu, who had once been chairman of the Defence Force Retirement Benefits Fund and more recently the church development officer for the Evangelical Church of Papua New Guinea. He utilized the metaphor of a hand-mark to emphasize that

12 Some people were not even able to identify him when shown a photograph I had taken. 
he had already made his mark elsewhere in Papua New Guinea and now wanted to do so for Kagua-Erave ('Nau mi laik putim han mak long Kagua-Erave'). His poster featured three photographs of separate buildings, the last with his hand superimposed, as a reference to his work in the superannuation industry and their investments around the country. He did list some policies, overlaying one on each finger of the large image of a hand, including church, women and youth, law and order and health. Donald Yaki Rambua, standing as an independent, had a brief policy list on his poster, one of which was to support the work of the churches in Papua New Guinea.

During the campaign period, I was based in the village of Ibia, in Ibia council ward, Aiya in Kagua-Erave electorate. Here, the face of Christianity is changing and churches of different denominations are proliferating, as is happening throughout Papua New Guinea. In the past each village would have a single church of the denomination that had established Christianity in the region during the colonial period. With a population of about one thousand people, Ibia council ward has several newer churches besides the first-established Catholic Church, including the Assemblies of God, the Bible Missionary Church, the Church of God, the United Pentecostal Church, the New Apostolic Church, the Church of Christ and the Lutheran Church. Also, some residents were members of other churches, such as Seventh-day Adventist, Revival Churches of PNG or the United Church situated in a nearby village.

This council ward was typical of many in the Southern Highlands, not only for its religious diversity but also for the distinct absence of the 'hand of the government', as people say (see also Haley 2008). The aid post at Ibia was derelict and had not been staffed for several years, though more recently it had received boxes of supplies from AusAID, which appeared to have been distributed by a self-proclaimed 'doctor' with no medical training. ${ }^{13}$ The local primary school also had an erratic existence and appeared to have been closed for a number of years, largely due to the failure of the so-called 'free education' policy, which has seen supplies to schools consist of dusters and chalk and not much else. Though it is currently open and has more than 400 students, it is severely understaffed, having only four teachers instead of the eight it should have. These are supplemented by three teachers' assistants, adolescents who have attained a year 10 education, but who have no training. The teachers run two classes simultaneously, moving between the two to spend half a period in one and half a period in the other. The bush-material buildings have galvanised iron roofs, funded by a local council grant, but overall the facilities are very basic, with rough hewn desks and chairs and a library with no books.

13 It was difficult to arrive at a definitive date, since people had a vested interest in presenting their situation as particularly hard. The date of 2001 was given by the local councillor, though others claimed it was of the order of 10 years or more. 
Though many hoped that their local candidate would be elected and that some services would be delivered, pessimism about the prospects of improvement in the local conditions was widespread. While the failures of the state cause much of this feeling that adversity is inevitable, the kinds of Christianity espoused also encourage it, especially the newer churches, as I shall explain later.

\section{John Yano}

The village of Ibia was the home of one of the candidates for Kagua-Erave electorate, John Japhet Yano (see Figure 19.4), and so I was able to observe his campaign first-hand, and to interview him about his background and opinions. He was related to the powerful local leader, (Captain) Randa, who actively and financially supported his campaign. ${ }^{14}$ John was a 30 -year-old married man with one child, and formerly a primary school teacher at Imena Primary School (2004-2006) in the Sugu Valley, the district of his wife and the sitting member, David Basua. It was his first time as a candidate and would probably be his last, as the campaign was very costly for someone who did not have a large resource base.

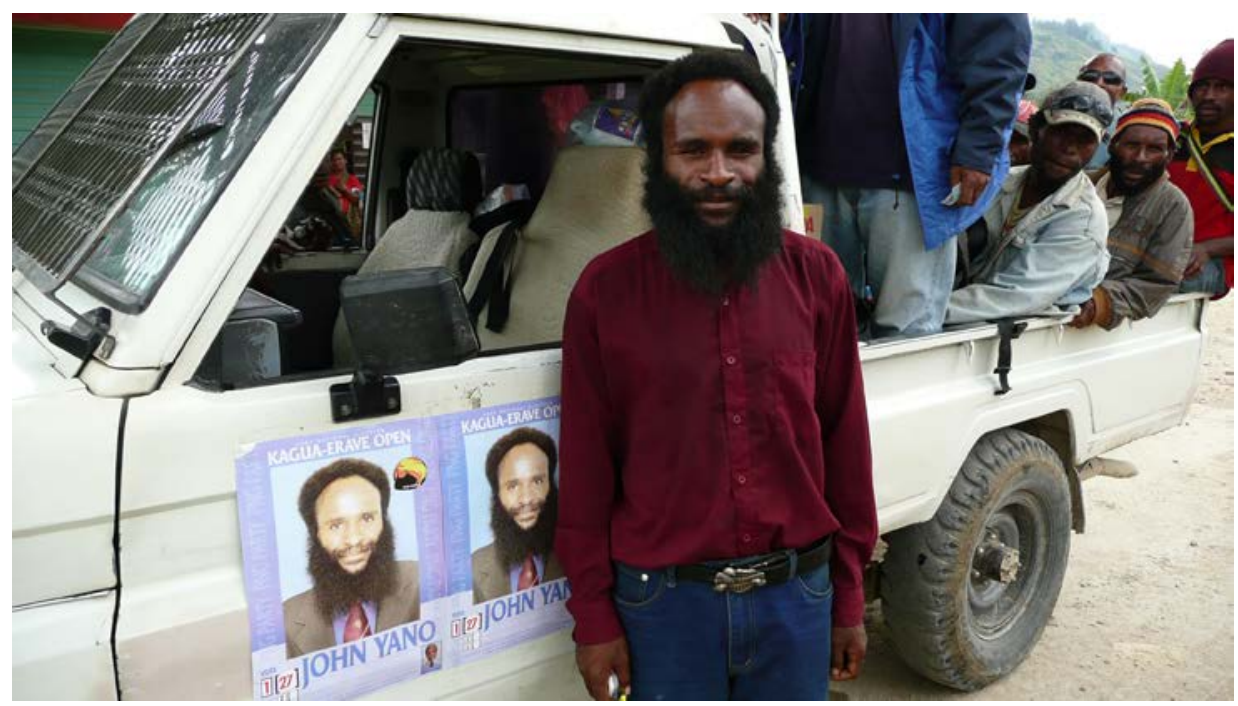

Figure 19.4: John Yano, PNG Party candidate for Kagua-Erave

John was a devout Christian, a member and leader of the Church of Christ or Lokal Sios, as it is called. Like the other 'born again' churches, this church opposed the participation of leaders in the electoral process. He was therefore suspended from his role as church leader and forbidden to preach or even initiate

14 Ibia Council ward comprised Ibia 1 and Ibia 2. Ibia 1 consisted of the following villages: Mai, Wokuma, Maribit, Molonda, Rakenda, Ibia, Arepe, Koi, Rendenasu, Petame and Kerelum. Ibia 2 consisted of Mutulum, Alalu, Wariputi, Yamerika, Mambu, Umbu Mapalu and Asala. 
the singing in church, reduced, as he termed it, to being a 'kristian nating', who had to sit with the rest of the congregation. After the election, if not elected, he would be 'disciplined' for a further two to three months, after which he would have to kill a pig or organize a feast to which the leaders of the other 26 lokal sios in the Southern Highlands would be invited. There, they would pray over him and 'release him', allowing him to resume his leadership role in the church.

Somewhat contradictorily, it was largely at the behest of the church that he had stood as a candidate. This exemplifies the general ambivalence towards politics displayed by many of the 'born again' churches. On the one hand, they object to their members taking an active role in the electoral process, but on the other hand, they are acutely aware of failings of the current politicians and the need for better political leaders. Motivated by a church member's dream, in which God expressed his wish for a member who could bring services to the people of the electorate, the church leaders decided that it would be good for John to stand as a candidate. In their discussions, they turned to the Bible and saw the story of Moses leading the people to the promised land as a sign that God would single out a leader in difficult times. They told John that if God wanted to raise him in this way and give him this kind of power, it was something that God could do. They also compared John to David in his struggle with Goliath.

Despite these Biblical allusions, Christianity did not feature much at all in John's campaign. As noted above, this was generally the case for other candidates. John did advocate a tithing policy of 10 percent, which would go to small 'born again' churches such as his own, mainly to help purchase musical instruments, lamps and kerosene for use at rallies, camps and crusades. This was less ambitious than another PNG Party candidate (for the Imbonngu Open seat) who promised to supply electricity to all the churches in the electorate, a very ambitious task given the lack of infrastructure in the area and the proliferation of small churches, many of whose assets consist of little more than a bush-material house and a congregation no bigger than an extended family.

John would undoubtedly have been considered one of the 'God-fearing' candidates that public discourse sees as desirable leaders, even though his Christian identity and beliefs were rarely mentioned in his campaign. In interviews about broader issues, he and his church appeared very fundamentalist in outlook, with the usual strong emphasis on being born again, repudiating one's past life and a belief that good Christians would be whisked away in the Rapture prior to the Last Days. Also, as is usual, these Christians placed great emphasis on personal morality and were required to forsake many practices, ranging from drinking to playing sport. The maintenance of strict sexual morality was also considered important, particularly marital fidelity. A man was required to marry a Christian, preferably from within the same church, and polygamy and divorce were not permitted. 
Like some of the candidates standing in other electorates, John presented himself as a village man ('man bilong ples') or as he termed it, 'manki bilong bus tasol', - that is, as a person who did not have money or vested interests at stake and who could truly represent the wishes and aspirations of the villagers. Further, as a teacher who had worked in a remote rural community school, he believed he was aware of the needs of the rural villagers he sought to represent. Despite his identification as a 'grassroots' man, he could hold his own with other more educated and worldly candidates in public speaking.

John owned one of the few cars in Aiya local-level government area (five for a population of approximately 21,000), given to him by his brother who works at Ok Tedi, and bought second-hand for K35,000. Like the other vehicles, it was unregistered and unroadworthy. Usually severely overloaded with his supporters, it barely staggered up the local hills and occasionally didn't. The campaign was reputed to have cost approximately K50,000. As a member of Mekere Morautu's PNG Party, John received a little funding from the party, enough to print one thousand campaign posters. Mainly, his funding was garnered from his relatives, local support base, and another PNG Party member, Francis Awesa, a wealthy businessman, and owner of Global Construction, a major road-building company in Papua New Guinea.

Like many candidates, John used the rhetoric of anti-corruption, good governance and anti-gifting, but was nevertheless forced to play the politics of gifting to secure the support of wavering voters. This involved making contributions to the sponsors of grandstands when he attended campaign rallies, and also handing out small amounts of cash to individuals and dispersing pigs. His priorities if elected were similar to those of other candidates: to bring development and services (sevis) to the electorate. This is an obligatory promise in Papua New Guinea electoral politics, having irrefutable appeal since nobody would contest the need for better roads, schools and hospitals. In Kagua-Erave electorate he saw road services as the greatest need, followed by schools, aid posts and then the development of plantations to utilize the large labour pool in the electorate. Well informed of the number of voters in each council ward and of how much support they had, John's close supporters were convinced of victory, with all the confidence of cargo cultists that the goods would be delivered. Three weeks before polling, John confidently predicted that he had the support of 16 out of 24 council wards in the local-level government area, a confidence buoyed by the dreams of many supporters. Reputedly there had been 101 dreams predicting his victory. However, the predicted support did not eventuate and he was not successful in winning the seat, though he was fourth in the contest with nearly 10 percent of the first preference vote. 


\section{Local churches and politics}

Prior to the polling, I also interviewed a number of the pastors of the newer churches in Ibia to ascertain their broad religious outlook and their attitude to politics, electoral politics in particular. I met with pastors of the Church of God, the Assemblies of God, the Bible Missionary Church, and a previous member of the Christian Revival Centres of Papua New Guinea.

All of these churches put great stress on the radical conversion experience of 'tanim bel' or being born again, with its emphasis on personal morality and bodily purity. To attain this purity, these churches prohibit many forms of behaviour besides the usual Biblically named sins. While there is some minor variation, particularly in relation to some aspects of local custom, such as mortuary rites and bride-wealth payments, the churches are broadly similar in their proscriptions, which include smoking, drinking alcohol, chewing betel nut, card-playing and sport. The latter is often associated with pride, but is also banned because the clothing worn during games exposes the body to the view of the opposite sex. Polygamy and divorce are not allowed, since family life is considered a mainstay of the church community. It is forbidden for a husband to beat his wife and in some churches married couples are counselled if conflicts occur. All of these churches can properly be called fundamentalist, seeing the world essentially as a crucial struggle between Satan and Christ. Some are Pentecostal and recognise that baptism by the Holy Spirit can bring miraculous gifts, such as healing and prophecy.

Most of these churches held similar views on involvement in electoral politics, banning it and suspending members and leaders who broke the prohibition. The Church of God forbade all members to stand for election and for the pastor to support any candidate. According to their pastor, John Kuma, while a pastor had the right to vote as he wanted, he was not allowed to speak publicly in favour of a particular candidate. In Pastor Kuma's view, politics is associated with candidates' desire to increase their own prestige and renown (apim biknem bilong yu iet) and consequently they made many promises that they would not fulfil when elected. Like other Christians avoiding direct involvement in politics, members of this church placed much faith in prayer, asking God to show them a leader who would look to the needs of all Christians and provide them with much needed schools, roads and bridges. Pastor Kuma felt that electoral politics in Papua New Guinea was characterized by many lies and much trickery, in contrast to Australia and America, where he believed politicians were trustworthy and elections valid. He was sceptical about the ability of elected members to bring development to their communities and, indeed, he thought that before long the nation of Papua New Guinea would collapse completely 
and another country would take over. He would not suggest which country this might be, but he did say that many people believe that preparations for a takeover are currently under way.

The Christian Revival Centres also eschew involvement in politics. Contesting a seat in the elections is forbidden and any member choosing to do so is suspended. If a church leader contests an election, he is also suspended from church membership and is required to work his way back up to any leadership role following suspension. Neither can a member actively support a candidate by participating in campaign activities. The church refuses to accept donations from politicians and candidates or associate with other churches that do. Indeed, it was said that they would not attend the peace march and rally in Mendi for this reason. This eschewal of politics was explained in terms of politics and God's word being contradictory: 'You cannot preach God's word, you cannot be a Christian and do politics at the same time'. On another occasion this informant described this as being like light and darkness, which are opposites and cannot mix.

The Assemblies of God took a similar radically dualist position. A member of this church was contesting the Mendi Open seat, and since this was not permissible, he was suspended from church membership. The pastor, Roki Awepe, said that although a candidate for Kagua-Erave (John Yano) was his 'brother', he was not permitted to accompany or assist him in the campaign, which, for him, would mean breaking the laws of the Bible. As a Christian, he must think only of God and God's word. Involvement in electoral politics would conflict with Christianity, since the kinds of thought involved were mutually opposed. Faith, he said, requires one hundred percent commitment not partial or competing commitments. Moreover, he believed that involvement in politics was corrupting, as earthly thoughts would inevitably arise, destroying his Christian life and leading him astray from Jesus.

This pastor considered that much as the year 2000 was a 'Year of God', so too was 2007. Therefore, it was desirable that 2007 should be a peaceful time. Since the electorate of Kagua-Erave was not a good place and was full of greedy people, when members were elected in the past, they just consumed the money and didn't bring any services to the electorate. Pastor Awepe instituted a program of prayer to be followed by his congregation which sought to ensure that the election was not characterized by 'trouble'. He hoped God would remove any bad leaders and ensure that only good leaders were elected. Personally, he was going to seek guidance from God about who to vote for, and if his spirit spoke to him he would follow this guidance.

Pastor Awepe thought that in this Year of God they should be looking for signs of the end times. Like Pastor John Kuma of the Church of God, Pastor Awepe 
thought that a takeover of Papua New Guinea was imminent and would occur after the election. While on first reflection it may appear that he was alluding to the kinds of interventions into fragile and failing states that have occurred in recent years, such as the Regional Assistance Mission to Solomon Islands or the Enhanced Cooperation Program intervention in Papua New Guinea, his reference was decidedly Christian. Satan was behind this 'take-over' and he believed that following the election Satan's distinctive number 666 would be visible in Papua New Guinea. As he remarked:

The one world mission, one world government, all these kinds of things they have prepared them and they are ready but they are waiting for this government, all the new members to go to parliament and form a new government and administration. OK, after this they will declare it and they will start to use this number and start to use the new law of the one world mission and one world government.

He went on to say that 'they' had already recorded where everybody lives and that as part of the new order, members of the Catholic Church were singled out to receive projects from the pope. As all Catholics are registered and their names recorded on a computer, they were eligible to receive the projects they wished for-small-scale development projects such as sawmills and farms. Though he did not say so, such stories usually mention that supporters of Satan have the number 666 tattooed on their foreheads and hands, and that those who do not wish to join with him are beheaded.

The Bible Missionary Church has much the same policies towards elections as the churches described above. Members are forbidden to stand for election or be involved in politics and are suspended if they do so. The pastor, Simon Ewa, also believed that candidates in elections do not always tell the truth, a patently unchristian behaviour. He saw his role as giving guidance to his congregation, giving them good thoughts, so that they would remain good Christians and live the life needed to get them to Heaven. He encouraged the congregation to pray for guidance from God on whom to vote for and for help in choosing the right leader. Members of this church also subscribed to beliefs about the end times and the idea that this would be marked by the ascendancy of the one world mission, one world government and the number 666. Pastor Ewa believed that this apocalyptic scenario was set out in the Bible, though it also appears that his beliefs were influenced by foreign missionaries from his church, as well as rumours and stories. Like the Assemblies of God pastor, he believed that this would all be revealed after the election.

We are waiting for the government to go inside [parliament] and OK the 666 number. It is all ready and is just waiting for the next elected 
government to go to parliament and sign the necessary papers. The number has arrived and is waiting. Once the politicians have signed the papers, the number will be revealed.

Although he believed that this new world order would be controlled by one man, he did not connect it to the Catholic Church, as some do, suggesting that the Bible is not clear on who this man is. ${ }^{15}$ People would be under the control of this man and they would bear the number on their forehead or body. If this man said that they must go to church they would go to church. If he said that they must do nothing, they would do nothing. If he told them to do some kind of work they would carry out the order.

These kinds of belief are characteristic of many of the fundamentalist evangelical, charismatic and Pentecostal churches, ${ }^{16}$ many of which are premillennialist. ${ }^{17}$ Premillennialism predicts that Christ will return to rule over the earth for a thousand years. This will be preceded by the end times, a period of widespread social and economic disintegration, climatic changes and natural disasters (Boyer 1992; Weber 1987; Eves 2000). ${ }^{18}$ Many adherents see the present as just such a time of disintegration and disaster, pointing to the increasing levels of corruption, raskolism and the AIDS epidemic as clear signs of the end times. One aspect of this rather pessimistic view is the prophecy that Satan or the Anti-Christ will take over the world for a period, before being defeated by Christ, and the allusions by some of the pastors referred to above to the 'one world mission' and 'one world government' are examples of this.

As most premillennialists believe Christ's return is imminent they await it anxiously (though if good Christians they are spared the tyranny of the AntiChrist's rule, since they are whisked away in the Rapture), conducting their lives in perpetual readiness, keeping themselves sin free and evangelizing zealously. In obedience to Christ's request to spread the Word to all nations, called the Great Commission, they believe it imperative to convert as many people as possible before the end times. Some believers seek to spread the gospel in the belief that Jesus will return when all nations have been evangelized (Brouwer, Gifford and Rose 1996:18).

15 When I suggested that some people single out the pope he refuted this, saying God would not 'bagarap' another man.

16 Especially in Pentecostal churches, and those mainstream churches influenced by Pentecostalism.

17 Seventh-day Adventists also subscribe to premillennialism and put great stress on the end times scenario set out in the Book of Revelation.

18 This contrasts with the more optimistic postmillennialists who believe that it is possible through human effort to bring on the reign of Christ and who expect the conversion of all nations to Christianity prior to Christ's return (see Erickson 1977:55; Ammerman 1991:7; Wessinger 1997:49). 


\section{Conclusion}

As events unfolded following the election, it is clear that the predictions of a post-election takeover of Papua New Guinea have not taken place. How Christians such as these pastors have made sense of this, and what effect it has had on their premillennial ideas, cannot be answered here.

It is difficult to judge how widely these kinds of beliefs about the post-election takeover of Papua New Guinea are embraced by the general population. Such beliefs became apparent to me as a consequence of rather lengthy interviews with Christian leaders and it is unlikely that they would be conveyed in everyday casual discussions. Moreover, church leaders have a much fuller understanding of Biblical prophecy than their congregations, so it is likely that the knowledge of others is more fragmentary. Certainly, these ideas are not nearly as elaborated in the Southern Highlands as I have found elsewhere in Papua New Guinea. In New Ireland, for example, there is a much more developed understanding and interpretation of these Biblical prophecies (see Eves 2000, 2003). This is probably a consequence of the longer history of Christianity there, as well as the higher levels of literacy and the greater availability of Christian literature that details these predictions.

Even in their nascent and fragmentary state, the taking up of these ideas indicates a profound disenchantment with political processes and governance in Papua New Guinea. Moreover, the failings of the government in running the 2007 election in the Southern Highlands has undoubtedly reinforced the widespread disenchantment with the governance of Papua New Guinea. It is inevitable that the state's incapacity to deliver services will be seen as proof of the validity of the end times scenarios described above.

The relationship between politics and religion in Papua New Guinea could perhaps best be described as thorny. On the one hand, their general aversion to politics leads many of the newer evangelical, charismatic and Pentecostal churches to shun active involvement in the electoral process and in politics more generally. On the other hand, these Christians often voice sharp criticisms of the failings of the government, longing for better governance, and especially the delivery of services. Although people are longing for better times and their criticisms are generally legitimate, due to their firm belief in the Biblical prophecies of the end times, they actually anticipate that the situation in Papua New Guinea (and elsewhere) will get progressively worse rather than better. In other words, rather than basing their critique on analysis of the social and structural factors which have led to the creation of inequality in Papua New Guinea, and the devastating failure of services, the Christians see these occurrences as part of the inevitable unfolding of God's plan. This means 
that human intervention attempting to change the course of events is futile. As Gifford argues, this actively disempowers adherents, promoting a 'passive acceptance of disasters, misfortune and a lack of social responsibility' (1991:9). Rather than political activism, premillennialism stresses personal salvation, evangelism and prayer which are all that can be done within the compass of its beliefs.

\section{References}

Ammerman, N. T., 1991. 'North American Protestant fundamentalism', in M. E. Marty and R. S. Appleby (eds.), Fundamentalisms Observed. Chicago: The University of Chicago Press, pp.1-65.

Asia Pacific Network 1997. Online document: http://www.asiapac.org.fj/ cafepacific/resources/aspac/korowi.html

Boyer, P., 1992. When Time Shall Be No More: Prophecy Belief in Modern American Culture. Cambridge, Mass.: Belknap Press of Harvard University Press.

Brouwer, S., Gifford, P. and Rose, S. D., 1996. Exporting the American Gospel: Global Christian Fundamentalism. London: Routledge.

Erickson, M. J., 1977. Contemporary Options in Eschatology: A Study of the Millennium. Grand Rapids: Baker Book House.

Eves, R., 1996. 'Colonialism, corporeality and character: Methodist missions and the refashioning of bodies in the Pacific', History and Anthropology 10(1):85-138.

Eves, R., 1998. The Magical Body: Power, Fame and Meaning in a Melanesian Society. Amsterdam: Harwood Academic Publishers.

Eves, R., 2000. 'Waiting for the day: globalisation and apocalypticism in central New Ireland, Papua New Guinea', Oceania 71(2):73-91.

Eves, R., 2003. 'Money, mayhem and the beast: narratives of the world's end from New Ireland (Papua New Guinea)', Journal of the Royal Anthropological Institute 9(3):527-547.

Gibbs, P., 2004. 'Democracy and Enga political culture', in P. Gibbs, N. Haley and A. McLeod, 'Politicking and voting in the highlands: the 2002 Papua New Guinea elections'. State, Society and Governance in Melanesia Discussion Paper 2004/1. Canberra: State, Society and Governance in Melanesia Program, The Australian National University, pp. 2-15. 
Gibbs, P., 2005. 'Political discourse and religious narratives of church and state in Papua New Guinea', State, Society and Governance in Melanesia Working Paper 2005/1.

Gifford, P., 1991. 'Christian fundamentalism and development', Review of African Political Economy 18(52):9-20.

Haley, N., 2008. 'When there's no accessing basic health care: local politics and responses to HIV/AIDS at Lake Kopiago, Papua New Guinea', in L. Butt and R. Eves (eds), Making Sense of AIDS: Culture, Sexuality, and Power in Melanesia. Honolulu: University of Hawaii Press, pp. 24-40.

Haley, N. and May, R. J., 2008. 'Introduction: roots of conflict in the Southern Highlands', in N. Haley and R. J. May (eds), Conflict and Resource Development in the Southern Highlands of Papua New Guinea. State, Society and Governance in Melanesia Studies in State and Society in the Pacific, No. 3. Canberra: ANU E Press, pp. 1-19.

Hauck, V., Mandie-Filer, A. and Bolger, J., 2005. 'Ringing the church bell: the role of churches in governance and public performance in Papua New Guinea', Discussion Paper No. 57E. Maastricht: European Centre for Development Policy Management.

Ireland, R., 1995. 'Pentecostalism, conversions, and politics in Brazil', Religion 25(2):135-145.

Jorgensen, D., 2005. 'Third wave evangelism and the politics of the global in Papua New Guinea: spiritual warfare and the recreation of place in Telefolmin', Oceania 75(4):444-461.

Lewis, N., 2008. 'Conflict and vulnerability assessment of the Southern Highlands Province', in N. Haley and R. J. May (eds), Conflict and Resource Development in the Southern Highlands of Papua New Guinea. State, Society and Governance in Melanesia Studies in State and Society in the Pacific, No. 3. Canberra: ANU E Press, pp. 149-164.

Operation World, 2008. Online document: http://www.operationworld.org/ country/papu/owtext.html

Schmid, C. K., 1999. 'Rainforest dreams and millennial nightmares', in C. K. Schmid (ed.), Expecting the Day of Wrath: Versions of the Millennium in Papua New Guinea. Boroko: National Research Institute, pp. 1-33. 
Schoffeleers, M., 1991. 'Healing and political acquiescence in African independent churches', in C. Hallenscreutz and M. Palmberg (eds), Religion and Politics in Southern Africa. Uppsala: Scandinavian Institute of African Studies, pp. 89-108.

Weber, T. P., 1987. Living in the Shadow of the Second Coming: American Premillenialism, 1875-1982. 2nd edition. Chicago: University of Chicago Press.

Wessinger, C., 1997. 'Millennialism with and without the mayhem', in T. Robbins and S. J. Palmer (eds), Millennium, Messiahs, and Mayhem: Contemporary Apocalyptic Movements. London: Routledge, pp. 47-59. 